\title{
Endrin, DDT and PCB's in Finnish soils
}

\author{
Jorma RautapäÄ and Arvo MYllymäki \\ Agricultural Research Centre, Institute of Pest Investigation, 01300 Vantaa \\ Hilkka Siltanen and Veijo Mattinen \\ State Institute of Chemistry, Liisankatu $8 \mathrm{~g}, 00170$ Helsinki
}

\begin{abstract}
The highest endrin residue in 15 forest soil samples was $0.2 \mathrm{ppm}$, which is nearly twice the amount of endrin sprayed on the area in one treatment. In 6 analysed garden soils the maximum residue was $0.13 \mathrm{ppm}$, which is equivalent to one treatment. In general, endrin had not significantly accumulated in these soils, even after many years of use. The endrin residues did not correlate with the quantities used or the type of soil.

DDT or its metabolites were discovered only from two forest areas and one garden area. The highest residue was $0.02 \mathrm{ppm}$.

PCB's with low chlorine content $(42 \%$ of $\mathrm{Cl})$ were not found, but a high-chlorinated compound $(60 \%$ of $\mathrm{Cl})$ was discovered from six forest soils, the highest residue being $0.1 \mathrm{ppm}$.
\end{abstract}

In Finland endrin has been used to protect fruit trees, other garden plants and forest trees against injury by the voles, Microtus $s p p$., since 1958. The financial value of losses by voles to the horticulture and forestry was considerable in the 1950's and 1960's (KANERvo and MyLlymäki 1970, MyLlymäki 1975). The total amount of endrin used from 1958 to 1971 , i.e. during the period it was freely available, was 6.8 tons a.i. (MARKKULA 1971).

Hard restrictions concerning the sale and use of endrin were enforced in 1971; since that time endrin can be used in seed orchards of forest trees, nurseries and commercial orchards only, and even here a special licence is issued separately for each treatment by the Pesticide Regulation Unit. The amounts and distribution of endrin applications during this latter period of supervised control have been as follows:

\begin{tabular}{lrrrr} 
Year & Seed orchards & Nurseries & Orchards & Total \\
\hline 1971 & 140.0 & 22.0 & - & 162.0 \\
1972 & 807.0 & 53.5 & 9.5 & 870.4 \\
1973 & 125.4 & 37.5 & 2.5 & 165.4 \\
1974 & 125.0 & 25.5 & 12.0 & 162.5 \\
1975 & 59.0 & 4.8 & 6.0 & 69.8
\end{tabular}


DDT has been widely used in Finland from 1945 until September 1971, when its legal use was restricted in treating forest saplings in nurseries.

PCB's have been used in the 1970's only by two factories in industry. After 1970 the amount used has been about 240-270 tons per year, most of this being products with low chlorine content $(42 \%$ of $\mathrm{Cl})$ and only a small proportion of higher chlorine content $(54 \%$ of $\mathrm{Cl}$ ). PCB's with $60 \%$ chlorine have not been used in industry after 1970 (see e.g. RAUtAPÄÄ 1972).

DDT and lindane residues in some Finnish sugar beet fields and endrin residues in garden soils have been studied previously (RAUTAPÄÄ et al. 1972). While the use of endrin is now concentrated to a few sites, it was necessary to check the endrin residues of soils of frequent use. As far as is known, the PCB's have not earlier been analysed from forest soils in this country. However, residues of PCB's have been detected in wild animals (KARPPANEN and HENRIKSSON 1971, 1974, Hattula 1973) and man (Karppanen and Kolho 1973).

\section{Material and methods}

Soil samples. Soil samples were taken from 21 sites, of which 4 were, as far as is known, untreated with endrin or other pesticides (controls $1-4$ in Table 1). There is a detailed record of the endrin treatments of the sampled areas (Table 1). Samples 1-10 were taken in October 1971 before the endrin treatments, and samples $11-21$ in May or June 1973. Because endrin is sprayed in autumn before snowfall, at least one year had elapsed from the last treatments in the sampling areas $5-10$, and about half a year in the areas $11-21$ at the time of sampling.

Ten samples from different places in each area were taken from depths of about $0-15 \mathrm{~cm}$ under the field layer. The sample did not contain vegetation or litter. The samples were stored at a temperature of $-30^{\circ} \mathrm{C}$. The analyses were started in May 1973.

A n a lyt ic a 1 procedures. The soil samples, dried for 48 hours at room temperature, were extracted in Soxhlet with hexane-acetone $(9+1)$ for 16 hours. Endrin, DDT and PCB's were determined by gas chromatography with electrone capture detector.

A p paratus. Gaschromatographs: I Varian Aerograph 1520 with $\mathrm{EC}\left({ }^{3} \mathrm{H}\right)$-detector; metal column $(1,5 \mathrm{~m} \times 2,3 \mathrm{~mm}), 3 \% \mathrm{SE}-30$ on Varaport $30,100 / 120$ mesh, AW, DMCS; glass column $(1,5 \mathrm{~m} \times 3 \mathrm{~mm}), 3 \%$ Dow 11 on Chrom W, 80/100 mesh, AW, DMCS; II Varian Aerograph 1400 with EC $\left({ }^{63} \mathrm{Ni}\right)$-detector; glass column $(1,5 \mathrm{~m} \times 3 \mathrm{~mm}), 5 \%$ GE XE-60 on Chrom W, 60/80 mesh, AW, DMCS; metal column (1 m $\times 2,3 \mathrm{~mm}), 5 \%$ OV-101 $+5 \%$ OV-210 on Varaport $30,80 / 100$ mesh, AW, DMCS.

Experimental extraction of samples. All soils were extracted with hexane-acetone $(9+1)$, and in addition 10 of the samples were extracted with methylene chloride-methanol $(9+1), 3$ with methylene chloride-methanol $(1+1)$, and one sample with hexane-isopropanol $(3+1)$. Before the extraction in Soxhlet, $0,5,10$ or $25 \%$ of water was added to the dried soils. All other methods described above gave similar results, except those with methylene chloride-methanol methylenchlorid-methanol $(1+1)$, which gave somewhat smaller results. 


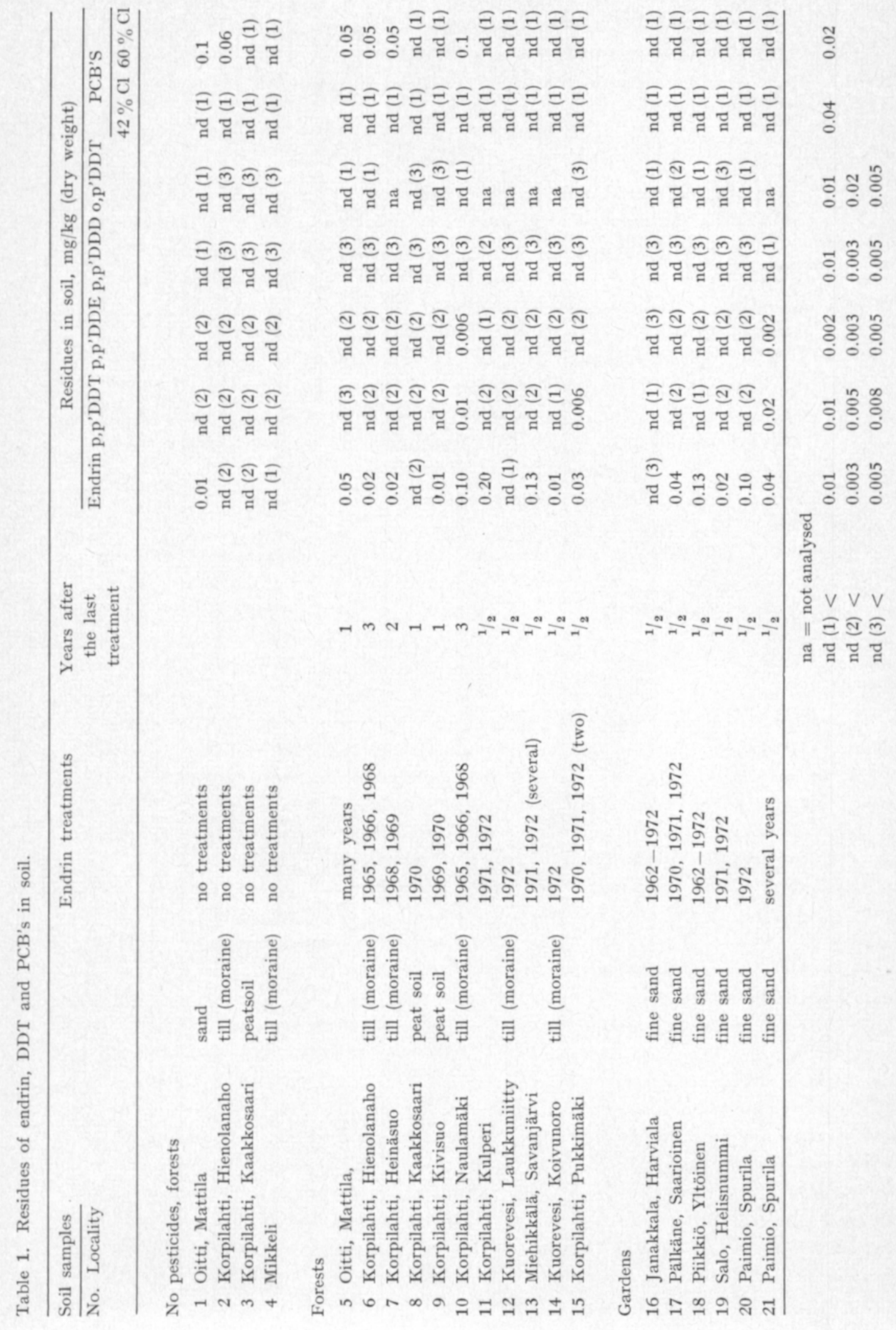


M e t h o d. The method used was the same as in previous study (RAUTAPÄÄ et al. 1972, see also SAmuel 1966, TeAsley and Cox 1966, Armour and BURKE 1970). Chromatograph mixture-cleaning was used in all samples.

\section{Results}

The highest residues of endrin in forest soils were $0.2 \mathrm{ppm}$ and $0.13 \mathrm{ppm}$ (samples 11 and 13, Table 1), and in garden soils 0.13 and $0.1 \mathrm{ppm}$ (samples 18 and 20$)$. A detectable amount of endrin $(0.008 \mathrm{ppm})$ was also found in one area considered to be untreated. On the other hand, no endrin was found in three areas where it had been used (samples 8, 12 and 16).

In the samples taken half a year later, the last spraying (samples 11-12) contained an average of $0.06 \mathrm{ppm}$ of endrin, and the forest soil samples taken at least one year after the spraying (samples 5-10), an average of $0.03 \mathrm{ppm}$. However, there was no correlation between the amount of endrin detected in soil and the dosage of endrin sprayed, the number of treatments or the type of soil.

DDT or its metabolites were found only from three samples the highest residue being $0.02 \mathrm{ppm}$.

No PCB's with $42 \%$ of chlorine were found from the samples. On the contrary, six samples contained PCB-compound with $60 \%$ of chlorine. The highest amount was $0.1 \mathrm{ppm}$.

\section{Discussion}

Endrin was found in one area where, as far as is known, it had not been used. A similar case was encountered previously from a garden soil (RAUTAPÄÄ et al. 1972). It is apparent that information received on the treatments was partly incorrect, or endrin maybe drifts at spraying over a wider area than is generally supposed. The samples considerad to be untreated were taken at a distance of several hundred meters from the treated areas.

The highest endrin residue in forest soils, $0.2 \mathrm{ppm}$ in sample 11 (Table 1), is equal to $0.4 \mathrm{~kg}$ of endrin in an area of one hectare in a layer of $20 \mathrm{~cm}(=2$ million $\mathrm{kg}$ of soil). This is nearly twice the amount of endrin spread over an area of one hectare in a single spraying if the treatment is carried out in accordance with the instructions. In other samples the residues in one hectare soil layer corresponded to an amount which is less than the amount of endrin sprayed in one treatment. Residues of endrin are known to have been found from soil many years after treatments (e.g. HARRIS and SANS 1971, CROCKET et al. 1974) and in general endrin is considered to be a relatively stable and in soil slowly decomposing pesticide (e.g. EDwards 1966, 1970). According to EDWARDS and THOMPSON 1973, the half-life in soil was at least two years and for example NAsH and Woolson (1967) found $41 \%$ of endrin left in soil after 14 years of treatment. Even though in Finland forest and garden soils stay frozen for several months during winter, the average residues of endrin were relatively small. It seems hardly likely that endrin could accumulate in soil even on areas treated continuously during many years. 
It is generally known that pesticides remain more stable in soils with a high humus content than in soil with a low humus content. The present results do not reveal any differences between the three main types of soil in these samples, till, peat soil and silt or fine sand.

PCB's with low chlorine content (about $42 \%$ of $\mathrm{Cl}$ ) are more seldom detected from wild animals or environment than products with a high chlorine content. For instance, in Finland, PCB's with $42 \%$ of $\mathrm{Cl}$ have been discovered from fish only in one area situated near a factory, where Arochlor 1242 (42\% of $\mathrm{Cl}$ ) had been used (Karppanen and Henriksson 1971). Although a great number of fishes, birds and seals have been analysed during the last few years, only PCB's with $60 \%$ of $\mathrm{Cl}$ have been detected (Karppanen and Henriksson 1971, 1974, Hattula 1973). The situation is similar to man: from tissues of workers exposed to PCB's of $42 \%$ of $\mathrm{Cl}$, only highly chlorinated PCB's $(60 \%$ of $\mathrm{Cl}$ ) have been detected (Karppanen and Kolmo 1973). The same phenomenon is evident also from the results of this study. It is not for the present study to clarify the reasons for this, but it is widely believed that PCB's with a low chlorine content are metabolised more rapidly than highly chlorinated PCB's and that commercial PCB-products of low chlorine content have as impurities some percentages of highly chlorinated PCB's. Whether the small residues of highly chlorinated PCB's in Finnish soils originate from impurities of low chlorinated PCB's used in this country or whether they are a result of a global pollution, is not known.

\section{REFERENCES}

Armour, J. \& Burke, J. 1970. Method for separating polychlorinated biphenyls from DDT and its analogs. J. Assoc. Off. Anal. Chem. 53: 761-768.

Crocket, A. B., Wiersma, G. B., Tai, H., Mitchell, W. G., Sand, P. F. \& Carey, A. E. 1974. Pesticidue residue levels in soils and crops, FY-70-National soils monitoring program (II). Pesticides Monit. J. 8, 2: 69-97.

Edwards, C. A. 1966. Insecticide residues in soil. Residue Rev. 13:83-132.

- -1970 . Persistent pesticides in the environment. In "Critical reviews in environmental control, 1, 1:7-67. Publ. Chemical Rubber Co., Cleveland, Ohio, U.S.A.

- - \& Thompson, A. R. 1973. Pesticides and the soil fauna. Residue Rev. 45:1-79.

HARRIS, C. R. \& SANS, W. W. 1971. Insecticide residues in soils on 16 farms in Southwestern Ontario - 1964, 1966, and 1969. Pesticide Monit. J. 5, 3: 259-267.

HatrulA, M. L. 1973. Analysis of DDT- and PCB-type compounds at low level in fish with reference to pike, perch and bream in lake Päijänne. Univ. Helsinki, Inst. Food Chem. \& Technol. EKT Series 301, 145 p.

Kanervo, V. \& Mүlцyмäкi, A. 1970. Problems caused by the field vole, Microtus agrestis (L.) in Scandinavia. EPPO Publ. Ser. A, N:o. 58:11-26.

Karppanen, E \& Henriksson, K. 1971. DDT ja PCB kaloissa. Suomen Eläinlääkärilehti 12: $429-436$.

- - \& Henriksson, K. 1974. Kvicksilver- och klorerade kolvätehalter i havs- och insjösälar. Suomen Eläinlääkärilehti $80,7 / 8: 378-391$.

- - \& Kоцно, L. 1973. The concentration of PCB in human blood and adipose tissue in three different research groups. National Swedish Environment Protection Board, Publ. 1973: 4: 124-127. 
Markкula, M. 1971. Sales of pesticides in Finland 1970. Kemian Teollisuus 28, 8: 549-553.

MYLLYM ÄKI, A. 1975. Outbreaks and damage by field rodents and other harmful small mammals in Finland. Ecological Bulletins/NFR 19:17-36.

Nash, R. G. \& Woolson, E. A. 1967. Persistence of chlorinated hydrocarbon insecticides in soils. Science 157: 924-927.

RAUtAPÄÄ, J. 1972. The use of PCB compounds in Finland. Kemian Teollisuus 29, 8: 526528.

- - Siltanen, H., Valta, A.-L. \& Matrinen, V. 1972. DDT, lindane and endrin in some agricultural soils in Finland. J. Scient. Agric. Soc. Finl., 44: 199-206.

SAMUEL, B. L. 1966. An improved screening method for chlorinated and thiophosphate organic insecticides in foods and feeds. J. Assoc. Off. Anal. Chem. 49: 346-353.

Teasley, J. I. \& Cox, W. S. 1966. Method for extracting insecticides from soil. J. Agric. Food. Chem. 14: 519-520.

MS received January 5, 1976.

\title{
SELOSTUS
}

\section{Endriini, DDT ja PCB-aineet metsä- ja puutarhamaissa}

\author{
Jorma Rautapää ja Arvo Myllymäki \\ Maatalouden tutkimuskeskus, tuhoeläintutkimuslaitos, 01300 Vantaa 30 \\ Hilkкa Siltanen ja Veijo Mattinen \\ Valtion maatalouskemian laitos, Liisankatu $8 \mathrm{~g}, 00170$ Helsinki 17
}

Endriinin, DDT:n ja PCB-aineiden (polyklooribifenylien) määrät selvitettiin 15:sta metsämaa- ja 6:sta puutarhamaanäytteestä. Tutkittaviksi valittiin alueita, joilla endriiniä tiedettiin käytetyn pitkään ja usein. Suurin metsämaiden endriinimäärä oli $0.2 \mathrm{ppm}(=\mathrm{mg} / \mathrm{kuivapaino-}$ kilo), mikä vastaa lähes kahdesta ohjeiden mukaan tehdystä ruiskutuksesta hehtaarin alalle tulevaa endriinimäärää. Puutarhamaiden suurin endriinimäärå oli $0.13 \mathrm{ppm}$ ja se vastaa yhden ruiskutuksen seurauksena hehtaarin alalle joutuvaa endriinimääräa. Muissa maanäytteissä endriinipitoisuudet olivat pienemmät eikä näytä todennäköiseltä, että endriini olisi Suomen pitkästä talvesta huolimatta merkittävästi keräytynyt ruiskutettujen alueiden maahan.

Ruiskutusmäärät, ruiskutuskerrat tai maan laatu eivät selvästi vaikuttaneet maan endriinipitoisuuteen.

DDT:tä löydettiin vain yhdestä metsämaasta ja kahdesta puutarhamaasta. Suurin pitoisuus oli 0.02 ppm.

Vähän klooria $(42 \%)$ sisältäviä PCB-aineita ei löydetty lainkaan, mutta runsaskloorista $(60 \%)$ PCB-ainetta oli kuudessa maassa. Suurin pitoisuus oli $0.1 \mathrm{ppm}$. Suomessa on tiettävästi käytetty 1970-luvulla vain vähäkloorisia valmisteita, jotka hajoavat runsaskloorisia PCBaineita nopeammin ja joita ei tavallisesti löydy luonnonvaraisista eläimistä tai ympäristöstä. Tutkittujen maanäytteiden runsaskloorinen PCB-aine saattaa olla peräisin Suomessa käytetyistä vähäkloorisista valmisteista, joiden tiedetään sisältävän epäpuhtauksina pieniä määriä runsaskloorisia PCB-aineita. Maan runsasklooriset PCB-aineet poivat myös olla globaalisen saastunnan seuraus. 